\title{
Belgeo
}

Revue belge de géographie

\section{An outline of landscape science in Poland}

Aperçu de l'évolution de la science paysagère en Pologne

K.H. Wojciechowski, Ewa Skowronek and Andrzej Tucki

\section{(2) OpenEdition}

\section{Journals}

Electronic version

URL: http://journals.openedition.org/belgeo/13749

DOI: 10.4000/belgeo.13749

ISSN: 2294-9135

\section{Publisher:}

National Committee of Geography of Belgium, Société Royale Belge de Géographie

\section{Printed version}

Date of publication: 30 September 2004

Number of pages: 321-328

ISSN: 1377-2368

\section{Electronic reference}

K.H. Wojciechowski, Ewa Skowronek and Andrzej Tucki, «An outline of landscape science in Poland », Belgeo [Online], 2-3 | 2004, Online since 14 September 2013, connection on 08 July 2020. URL : http:// journals.openedition.org/belgeo/13749; DOI : https://doi.org/10.4000/belgeo.13749

This text was automatically generated on 8 July 2020 .

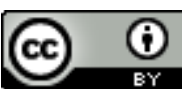

Belgeo est mis à disposition selon les termes de la licence Creative Commons Attribution 4.0 International. 


\section{An outline of landscape science in Poland}

Aperçu de l'évolution de la science paysagère en Pologne

K.H. Wojciechowski, Ewa Skowronek and Andrzej Tucki

\section{The history of landscape science in Poland}

1 The conception of landscape as a subject of study and a category useful in imparting geographic and regional knowledge appeared at the turn of the 19th century, in the works of several most distinguished geographers of the time (W. Pol, A. Rehman, E. Romer and S. Pawłowski among others), and took on a particularly interesting shape as «picturesque geography» postulated by W. Nałkowski. After years, the above conceptions, which formed a basis for regional research and syntheses, only survived in school geography, where landscape description was used to teach regional geography.

2 As early as in the 1950s, the Cracow academic centre initiated a broader research work on landscape architecture, while advancing the programme of landscape architecture teaching to students in architecture. At the beginning, the research mainly consisted in documenting and analysing heritage landscape systems; then, the problems of the conservation and renewal of the systems came within the scope of the study. At the same time, the Warsaw academic centre, connected with an agricultural academy, focused on urban green areas and the green surrounding representative objects.

Geographic landscape research, initiated a little later, at first concentrated on the issues of taxonomy, classification, evolution and functioning of landscape systems of different hierarchic order, identified as territorial nature complexes. Their properties were analysed using methods provided by relevant branches of physical geography (Bartkowski, 1970, 1977; Richling, 1982; Sołowiej, 1992).

4 The 1990s brought a breakthrough in the progress of landscape research, when the number of publications on the subject multiplied, followed by documentation of the practical use of the proposed solutions. It was then that the scope of the subject was 
broadened, the system of education changed, and a considerable increase in the number of institutions involved in landscape research and applying the findings of the science took place.

5 After many years' efforts, the profession of «landscape architect» received an official status, and several academic centres, apart from the Cracow and Warsaw centres, introduced or expanded this subject of study. The Warsaw centre, linked to the Department of Gardening and Landscape Architecture and Institute of the Landscape Architecture of Cracow Politechnic has long been educating architects specialising in landscape architecture. At the end of the 1990s, a separate programme of their education was created in Cracow and landscape architecture became an independent faculty. Periodically held Didactic Forums in Landscape Architecture help co-ordinate and integrate the efforts aimed at educating landscape architects.

6 At the same time, the scope of landscape works by geographers expanded and evolved, following the publication of interdisciplinary ${ }^{1}$ works on the problems of landscape, where the knowledge and methodology from the realm of ecology, sociology, psychology, history and cultural and art studies have been applied. Computer data processing, graphic techniques and computer cartography (mainly GIS) have become commonly used in research and the presentation of findings.

7 At present, the subject matter of the research encompasses the classification and evaluation of landscape, landscape perception and the application of landscape research in spatial planning. Many publications are concerned with the issue of landscape transformations in particular, and provide a comprehensive discussion of all aspects of qualitative features of landscape, often documenting the recent and contemporary processes. Geographers from all academic centres in Poland are now involved in landscape research, those from Warsaw, Poznañ, Sosnowiec and Lublin being the most active (German \& Balon, 2001).

8 The creation of the Polish Association for Landscape Ecology, an organiser of annual conferences and scientific seminars on the problems of landscape research, and the patron of a serial publication «Problems of Landscape Ecology», has been an important factor in animating and integrating landscape research.

9 A new Act of Parliament on nature conservation (1991) was a factor which greatly contributed to the intensification of landscape research in Poland in the 1990s. The Act introduced new types of protected areas - «landscape park» and «protected landscape area»-, as well as new requirements for environmental impact assessment of protected areas (including national parks). Considerable financial resources were allocated to the implementation of the assessments. Some of the statements, prepared by distinguished landscape researchers and concerned with the delimitation of protected landscape areas, the evaluation and typology of protected landscapes and the directions of their conservation, reveal an inovatory methodological approach and high substantial value (Chmielewski, 1990; Michalczyk (ed.), 2000). Nowadays, over 120 landscape parks and over 400 protected landscape areas function in Poland, besides its 23 national parks.

10 The cultural landscape conservation also gained in importance at the time, owing to the establishment of a new institution associated with the Ministry of Culture and National Heritage - the Centre for Heritage Landscape Conservation -, which supervises the governmental scheme for the compilation of heritage landscape inventory and issues a new periodical: «National Heritage Landscapes». 
11 The co-operation of various specialists in conducting landscape research, which has become closer in recent years and is manifest in both formal contacts and the growing congruity of attitudes to the question of the essential scope of landscape research, conservation and planning, has been institutionally confirmed. In 1998, the Ministry of Culture, the Ministry of Environment and the Ministry of Education signed an agreement providing for collective efforts towards landscape conservation and education. A year later, the Governmental Programme «Conscious Landscape Planning and Heritage Landscape Conservation» was ratified.

\section{Landscape types in Poland}

12 A natural landscape typology compiled by geographers was applied in Poland. When distinguishing landscape types, natural elements were considered the most important and their anthropogenic transformations were taken into account. In these terms, man is not regarded as an element of the natural system. The first such typology of natural landscapes was compiled at the end of the 1950s (Kondracki, 1960). A new version was prepared in the 1980s. The typology was published in a slightly modified and simplified form by Richling in 1992. Table1 presents an outline of the typological classification of natural landscape in Poland according to Richling².

13 A different division is used by landscape architects. It concerns the estimate of view amenities. This estimation is expressed in distinguishing natural landscape - or similar - areas (first amenities category) and harmonic agricultural landscape (second amenities category). These areas refer to the boundaries of natural landscape basic types (seaside landscape zone, lakeland, lowland, upland and mountain) (Fig. 1). 
Table 1. Types of natural landscape in Poland according to Richling (1992).

\begin{tabular}{|c|c|c|}
\hline Classes & Types & Sublypes \\
\hline \multirow[t]{4}{*}{ 1. Lowland landscapes } & 1. Glacial & $\begin{array}{l}\text { 1. plain and rolling } \\
\text { 2. hummocky } \\
\text { 3. hilly }\end{array}$ \\
\hline & 2. Periglacial & $\begin{array}{l}\text { 1. plain and rolling } \\
\text { 2. hummocky } \\
\text { 3. hilly }\end{array}$ \\
\hline & 3. Fluvioglacial & 1. plain and rolling \\
\hline & 4. Eolian & $\begin{array}{l}\text { 1. hummocky } \\
\text { 2. hilly }\end{array}$ \\
\hline \multirow[t]{3}{*}{$\begin{array}{l}\text { 2. Upland and low } \\
\text { mountain landscapes }\end{array}$} & 1. Loessic-eolian & $\begin{array}{l}\text { 1. of poorly-cut high plains } \\
\text { 2. of well-cut high plains }\end{array}$ \\
\hline & $\begin{array}{l}\text { 2. Carbonate and gypsum - } \\
\text { erosional }\end{array}$ & $\begin{array}{l}\text { 1. of compact massiis with rocks } \\
\text { 2. of isolated sloping heights } \\
\text { 3. of undulating plateaux }\end{array}$ \\
\hline & $\begin{array}{l}\text { 3. Siliceous and } \\
\text { aluminosiliceous - erosional }\end{array}$ & $\begin{array}{l}\text { 1. of foothills } \\
\text { 2. of single heights }\end{array}$ \\
\hline \multirow{2}{*}{$\begin{array}{l}\text { 3. Landscapes of high } \\
\text { and medium-high } \\
\text { mountains }\end{array}$} & $\begin{array}{l}\text { 1. Medium-mountain } \\
\text { - erosional }\end{array}$ & $\begin{array}{l}\text { 1. of the lower Tatra nappe } \\
\text { 2. of the upper Tatra nappe }\end{array}$ \\
\hline & $\begin{array}{l}\text { 2. High-mountain - } \\
\text { erosional and glacial }\end{array}$ & $\begin{array}{l}\text { 1. subalpine } \\
\text { 2. alpine } \\
\text { 3. subnival }\end{array}$ \\
\hline \multirow[t]{2}{*}{$\begin{array}{l}\text { 4. Valley and depression } \\
\text { landscapes }\end{array}$} & $\begin{array}{l}\text { 1. In inundated valley-floors } \\
\text { - depositional }\end{array}$ & $\begin{array}{l}\text { 1. of floodplains in lowland and } \\
\text { upland areas } \\
\text { 2. of floodplains in mountain areas }\end{array}$ \\
\hline & $\begin{array}{l}\text { 2. In supra-inundational } \\
\text { terraces - depositional }\end{array}$ & $\begin{array}{l}\text { 1. of terrace plains in lowland and } \\
\text { upland areas } \\
\text { 2. of terrace plains in mountain areas } \\
\text { 3. deltaic-depositional } \\
\text { 4. of swampy plains - depositional } \\
\text { 5. of denudation depressions and } \\
\text { basins in upland and mountain } \\
\text { areas - erosional }\end{array}$ \\
\hline
\end{tabular}

Source: Compiled by E.Skowronek on the basis of Bogdanowski J., 2000; Broniewski T., 1990; Cymerman et al., 1992; Miłobêdzki A., 1988; Maruszczak H., 1988.

Figure 1. The map of the types of the Polish natural landscape.

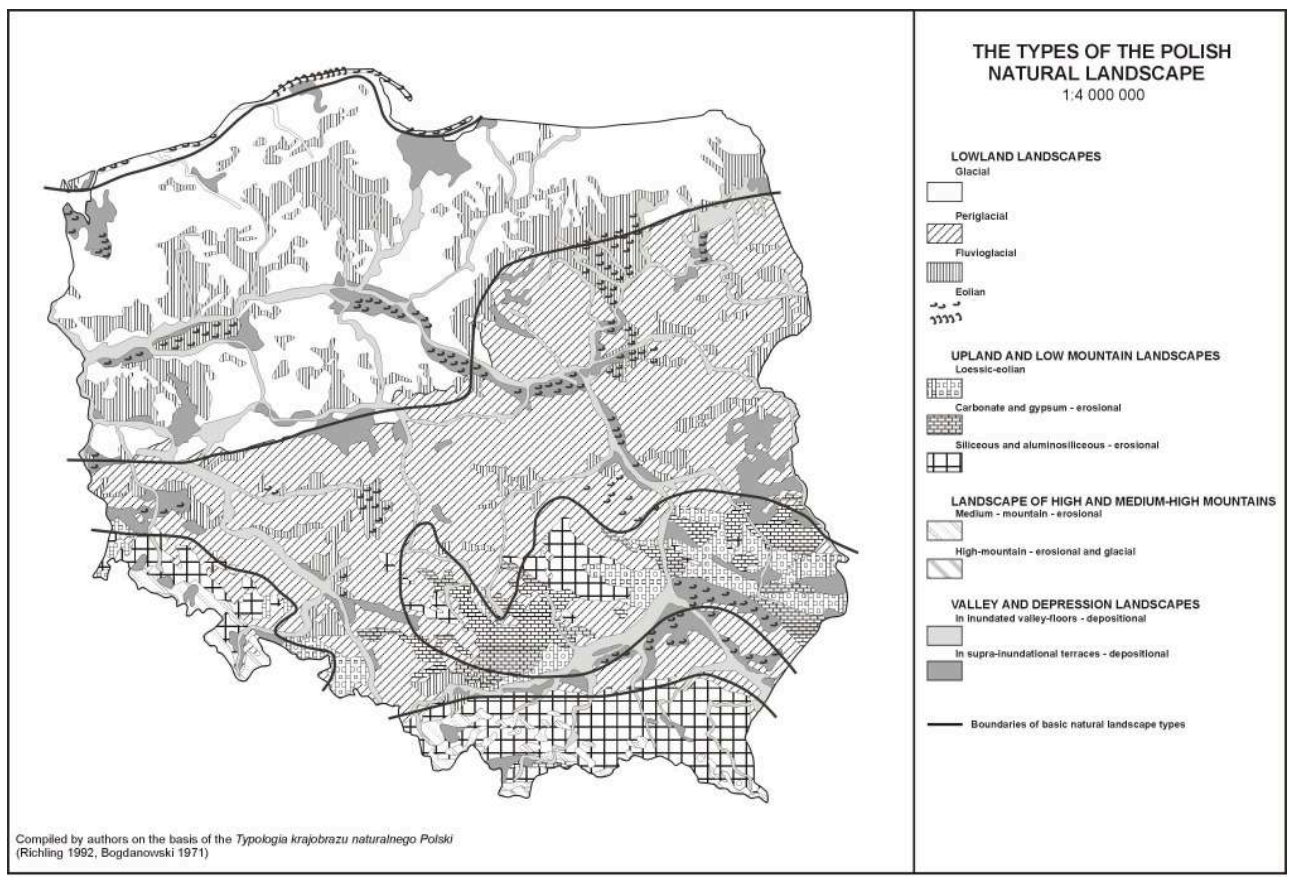

14 The progress of civilisation is a basis for natural (primeval) landscape transformation into varying forms, before it finally takes on the shape of a cultural landscape. Cultural landscape is therefore a manifestation of man's economic activity. All phenomena 
associated with a given civilisation, with social and economic relations etc., are usually reflected in the shape of the landscape (Bogdanowski, 2000).

\section{Stages of landscape development}

15 The economic history of Poland can be divided into several stages which substantially influenced the socio-economic transformations of the country, leading to the transformations of landscape space (Table 2).

Table 2. Stages of landscape development.

\begin{tabular}{|c|c|c|c|c|}
\hline $\begin{array}{l}\text { Major } \\
\text { landscape } \\
\text { type }\end{array}$ & $\begin{array}{l}\text { Landscape } \\
\text { development } \\
\text { phase }\end{array}$ & Duration & $\begin{array}{l}\text { Landscape } \\
\text { type }\end{array}$ & $\begin{array}{l}\text { Landscape } \\
\text { in a style }\end{array}$ \\
\hline primeval & $\begin{array}{l}\text { Phase of nomads } \\
\text { and natural } \\
\text { Holocene succession } \\
\text { of forest communities }\end{array}$ & $\begin{array}{l}\sim 10000- \\
\sim 5000 \mathrm{BP}\end{array}$ & Natural landscape & - \\
\hline natural & $\begin{array}{l}\text { Phase of primitive } \\
\text { community and the } \\
\text { beginnings of } \\
\text { agriculture }\end{array}$ & $\begin{array}{l}\sim 5000 \mathrm{BP} \text { to } \\
6^{\text {th }} \mathrm{C.AC}\end{array}$ & $\begin{array}{l}\text { Landscape of forests } \\
\text { and cultivated } \\
\text { clearings }\end{array}$ & - \\
\hline \multirow[t]{5}{*}{ cultural } & $\begin{array}{l}\text { Feudal economy } \\
\text { phase }\end{array}$ & $7^{\text {th }}-15^{\text {th }} c$. & $\begin{array}{l}\text { Forest and } \\
\text { agricultural } \\
\text { landscape }\end{array}$ & $\begin{array}{l}\text { - early-historical } \\
\text { - Romanesque } \\
\text { - Gothic }\end{array}$ \\
\hline & $\begin{array}{l}\text { Grange-farm - } \\
\text { corvée economy } \\
\text { phase }\end{array}$ & $\begin{array}{l}\text { from } 2^{\text {nd }} \text { half of } \\
\text { the } 15^{\text {th }} \mathrm{c} \text {. } \\
\text { till the end } \\
\text { of the } 18^{\text {th }} \mathrm{c} \text {. }\end{array}$ & $\begin{array}{l}\text { Agro-forestal } \\
\text { landscape }\end{array}$ & $\begin{array}{l}\text { - Renaissance } \\
\text { - Baroque } \\
\text { - classicistic }\end{array}$ \\
\hline & $\begin{array}{l}\text { Capitalist economy } \\
\text { phase }\end{array}$ & $19^{\text {th }}$ c. -1944 & $\begin{array}{l}\text { Agro-industrial } \\
\text { landscape }\end{array}$ & $\begin{array}{l}\text { - romantic } \\
\text { - eclectic } \\
\text { - naturalistic, } \\
\text { Secession } \\
\text { - modernist }\end{array}$ \\
\hline & $\begin{array}{l}\text { Socialist economy } \\
\text { phase }\end{array}$ & $1945-1989$ & $\begin{array}{l}\text { Industrial-agricultural } \\
\text { landscape }\end{array}$ & $\begin{array}{l}\text { - socialist } \\
\text { functionalism }\end{array}$ \\
\hline & $\begin{array}{l}\text { Phase of market } \\
\text { economy - post- } \\
\text { socialist }\end{array}$ & from 1989 & $\begin{array}{l}\text { Urbanisation } \\
\text { landscape } \\
\text { cultivated } \\
\text { recreational }\end{array}$ & $\begin{array}{l}\text { - modern } \\
\text { architecture }\end{array}$ \\
\hline
\end{tabular}

\section{Summary}

Recent years have seen a considerable growth of interest in landscape science in Poland. While former works on the subject mainly dealt with the development of the natural or socio-economic conditioning of landscape and its division (classification), typologies and regionalization, the present-day literature is more and more concerned with landscape ecology, which is landscape conservation and planning.

The ecological trend in the research is gaining interdisciplinary character: biologists, geographers, sociologists, physical planners carry out parallel and complimentary research. Scientists who show great interest in the issues include: A. Richling, A. S. Kostrowicki, J. Solon, J. Plit, J. Falkowski, J. Bogdanowski, M. Pietrzak, K. H. Wojciechowski, J.M. Matuszkiewicz. 


\section{BIBLIOGRAPHY}

BARTKOWSKI T. (ed.) (1970), Metodyka podziału kraju na mikroregiony dla potrzeb oceny œrodowiska przyrodniczego (Methodics of division into microregions in the evaluation of the natural environment), Zeszyty Naukowe UAM, Ser. Geografia, 138 p., Poznañ.

BARTKOWSKI T. (1977), Metody badañ geografii fizycznej (Research methods of physical geography), 544 p., Warszawa-Poznañ, PWN.

BOGDANOWSKI J. (1971), «Landscapes with predominance of natural and cultural elements preliminary distinguish (map)», Human environment problems, Biuletyn KPZK PAN, z. 68.

BOGDANOWSKI J., £UCZYÑSKA-BRUZDA M., NOVAK Z. (1979), Architektura krajobrazu (Landscape architecture), Warszawa-Kraków, PWN.

BOGDANOWSKI J. (2000), «Czytanie krajobrazu», Krajobrazy Dziedzictwa Narodowego («Landscape reading», National Heritage Landscapes), pp. 7-18, Warszawa, Oœrodek Ochrony Zabytkowego Krajobrazu, Narodowa Instytucja Kultury

BRONIEWSKI T. (1990), Historia architektury dla wszystkich (History of Architecture for Everybody), Wrocław-Warszawa-Kraków-Gdañsk, Ossolineum.

CHMIELEWSKI T.J. (1990), Parki krajobrazowe w Polsce. Metody delimitacji i zasady zagospodarowania przestrzennego (Landscape parks in Poland. Methods of delimitation and spatial management rules), 228 p., Warszawa, Wydawnictwo SGGW-AR.

CYMERMAN R., FALKOWSKI J., HOPFER A. (1992), Krajobrazy wiejskie (klasyfikacja i kształtowanie), (Rural landscapes (classification and planning)), pp. 53-70, Olsztyn, Wydawnictwo Art.

GERMAN K., BALON J. (ed.) (2001), Transformations of the natural environment of Poland and its functioning, The Problems of Landscape Ecology, vol. X, 813 p., Kraków, IGiGP UJ.

KONDRACKI J. (1960), «Typy krajobrazu naturalnego (œrodowiska geograficznego) w Polsce» («Types of natural landscape (geographic environment) in Poland»), Przeglad Geograficzny, 32, 1-2, Warszawa, PWN.

KOSTROWICKI A. S. (1992), System «Człowiek - œrodowisko» w œwietle teorii ocen, («Man-environment» system in the light of evaluation theory), Prace Geograficzne IGiPZ PAN 156.

MARUSZCZAK H. (1988), «Zmiany œrodowiska przyrodniczego kraju w czasach historycznych», w: Starkel L. (red.), Przemiany œrodowiska geograficznego Polski (Transformations of the natural environment of the country in historic times, in Starkel L. (ed.), Transformations of natural environment in Poland, pp. 109-137, Wrocław-Warszawa-Kraków-Gdañsk, Ossolineum.

MATUSZKIEWICZ J.M. (1981), Potencjalne zbiorowiska roclinne i potencjalne fitokompleksy krajobrazowe Pótnocnego Mazowsza (Potential plant assemblages and potential landscape phytocomplexes of the Northern Masovia Region), Monogr. Bot. 62, Kraków.

MATUSZKIEWICZ J.M. (1993), Krajobrazy roclinne i regiony geobotaniczne Polski (Vegetation landscapes and geo-botanical regions of Poland), Prace Geograficzne IGiPZ PAN 158.

MICHALCZYK Z. (ed.) (2000), Renaturalizacja obiektów przyrodniczych. Aspekty ekologiczne i gospodarcze (Renaturalisation of natural objects. Ecological and economic aspects), 290 p., Lublin, Wydawnictwo UMCS. 
MIEOBÊDZKI A. (1988), Zarys dziejów architektury $w$ Polsce (An outline of the history of architecture in Poland), Warszawa, Wiedza Powszechna.

PIETRZAK M. (1998), Syntezy krajobrazowe - załozenia, problemy, zastosowania (Landscape syntheses assumptions, problems, applications), 168 p., Poznañ, Wydawnictwo Naukowe.

PLIT J. (1996), Anthropogenic and natural transformation of vegetation landscapes of Poland's Mazowsze region (from the turn of the 19th century to 1990), Prace Geograficzne IGiPZ PAN 166, s: 135, Wrocław, Wydawnictwo Continuo.

RICHLING A. (1982), Metody badañ kompleksowej geografii fizycznej (Research methods of complex physical geography), Warszawa, PWN.

RICHLING A. (1992), Kompleksowa geografia fizyczna (Complex physical geography), Warszawa, PWN.

RICHLING A., SOLON J. (1994), «Ekologia krajobrazu» («Landscape ecology»), pp. 114-121, Warszawa, Wydawnictwo Naukowe PWN.

SOLON J. (1994) «The theoretical basis and methodological approaches to the evaluation of landscape stability», in Landscape research and its applications in environmental management, pp. 69-84, Warszawa, Faculty of Geography and Regional Studies, Warsaw University, Polish Association for Landscape Ecology.

SO£OWIEJ D. (1992), Podstawy metodyki oceny crodowiska przyrodniczego (Basic methodics in the evaluation of the natural environment), 172 p., Poznañ, Wydawnictwo Naukowe UAM.

WOJCIECHOWSKI K.H. (1986), Problemy percepcji i oceny estetycznej krajobrazu (Problems of perception and aesthetic evaluation of landscape), Rozprawy habilitacyjne UMCS 27 (Scientific dissertation UMCS 27), Lublin.

\section{NOTES}

1. The term «interdisciplinary» is used in the meaning «involving two or more disciplines or branches of learning» as defined by Webster's New World Dictionary (1984), as well as a number of other dictionary works.

2. The typology of landscapes contained in Table 1 has been adopted after «Complex physical geography» A. Richling (1992) and refers to a physiogeographic division and terminology commonly used in Poland.

\section{ABSTRACTS}

The article presents an outline of the progress in landscape science in Poland. Former works by Polish scientists mostly dealt with the development of natural or socio-economic conditioning of landscape and its division, typology and regionalisation, whereas, in the most recent Polish literature, more and more attention is devoted to landscape ecology, i.e., landscape conservation and planning. The article describes the phases of landscape development in Poland and the landscape types, which occur there. The interdisciplinary nature of the contemporary landscape 
research is pointed out and the main research schools are presented. The paper may serve as an element of a broader work on the progress of landscape science in Europe.

Cet article présente un aperçu de l'évolution de la science paysagère en Pologne. Auparavant, les travaux des scientifiques polonais traitaient principalement $\mathrm{du}$ développement $\mathrm{du}$ conditionnement naturel ou socio-économique du paysage, de ses découpages, de sa typologie et de sa régionalisation, alors que plus récemment, une attention croissante est consacrée à l'écologie paysagère, c'est-à-dire la conservation et l'aménagement du paysage. Cet article décrit les phases du développement paysager en Pologne, ainsi que les types de paysages qu'on y rencontre. La nature interdisciplinaire de la recherche actuelle dans ce domaine est mise en évidence, tandis que sont présentées les principales écoles de recherche. Cet article pourrait apporter une contribution à un travail plus vaste sur les progrès de la science paysagère en Europe.

\section{INDEX}

Mots-clés: géographie, science paysagère, écologie des paysages, Pologne

Keywords: geography, landscape science, landscape ecology, Poland

\section{AUTHORS}

\section{K.H. WOJCIECHOWSKI}

Department of Environment Protection, Institute of Earth Sciences, University of Maria CurieSkłodowska, Lublin, Poland, enviguci@biotop.umcs.lublin.pl

\section{EWA SKOWRONEK}

Department of Environment Protection, Institute of Earth Sciences, University of Maria CurieSkłodowska, Lublin, Poland, ewa.skowronek@umcs.lublin.pl

\section{ANDRZEJ TUCKI}

Department of Environment Protection, Institute of Earth Sciences, University of Maria CurieSkłodowska, Lublin, Poland, andrzej.tucki@umcs.lublin.pl 